\title{
GENETIC VARIABILITY AND ASSOCIATIONS BETWEEN GRAIN YIELD AND RELATED TRAITS IN AMARANTHUS CRUENTUS AND AMARANTHUS HYPOCHONDRIACUS GROWN AT TWO LOCATIONS
}

\author{
Olusegun A. ODUWAYE* ${ }^{1}$, Justina B.O. PORBENI ${ }^{1}$, Ibidun S. ADETILOYE ${ }^{2}$ \\ ${ }^{1}$ Department of Plant Breeding and Seed Technology, Federal University of Agriculture \\ P.M.B. 2240, Abeokuta, Nigeria \\ ${ }^{2}$ National Center for Genetic Resources and Biotechnology \\ P.M.B. 5382, Moor Plantation, Ibadan, Oyo State, Nigeria
}

Received: April 2016; Accepted: October 2016

\begin{abstract}
For plant genetic improvement, it is paramount to determine genetic components for the selection of desirable traits. Eighteen Amaranthus cruentus and 11 Amaranthus hypochondriacus genotypes were evaluated at two locations in Nigeria differing in temperature/precipitation to determine the influence of environment on genetic gain. Genotype $\times$ environment was significant for all analysed morphological parameters and for grain yield, 1000 seed weight and no. of days to 50\% flowering in A. cruentus. In A. hypochondriacus genotype $\times$ environment was significant for plant height, leaf length and width, leaf area, inflorescence length, 1000 seed weight and grain yield. Higher genotypic coefficient of variability, heritability estimates, and genetic advance was observed for the traits at Abeokuta (more wet) than Ibadan (more dry) conditions. Grain yield had positive association with the traits at the two locations except the number of leaves and inflorescence length. Inflorescence length was positively associated with grain yield at Abeokuta and negatively associated at Ibadan. Path analysis indicated simultaneous improvement of grain yield with petiole length and leaf length at Abeokuta but with petiole length and leaf area at Ibadan. In general, the locations had potential for genetic improvement of traits of amaranth grain; therefore, selection criteria for improving grain yield should be considered with respect to environment.
\end{abstract}

Key words: Amaranthus, genetic variability, heritability, path analysis, effect of environment

\section{INTRODUCTION}

Amaranth is one of the rare plants that are grown for grains yield. The grains are unique and nutritionally rich. The proteins are significantly reacher in essential dietary amino acids, particularly lysine, which is often limited in other cereal grains (Drzewiecki et al. 2003; Andini et al. 2013). The starch components are characterized by low gelatinization temperature, good stability during freezing and thawing, and high swelling power (Yanez et al. 1986). Also, oils from the grains have been noted for its high concentration of squalene, a lucrative ingredient used in cosmetics, skin penetrants and lubricants, and effective in reducing cholesterol (Gonor et al. 2006; Martirosyan et al. 2007). Many compounds and extracts from amaranths have antidiabetic, antihyperlipidemic, and spermatogenic effects (Sangameswaran \& Jayakar 2008; Girija et al. 2011) and antioxidant and antimicrobial activities (Alvarez-Jubete et al. 2010; Tironi \& Añón 2010).

Considering adverse effect of changing climatic conditions, amaranth is a promising agricultural crop with the ability to withstand negative effects of growing conditions (Alemayehu et al. 2014). The crop can adapt to diverse range of biotic and abiotic stresses (Grubben \& Denton 2004; Maundu \& Grubben 2004). However, despite the nutritional and agricultural importance of this crop (Bhuvaneswari et al. 2001), it is still one of the underexploited crops in 
Africa (Dubois \& Stoilova 2015; AVRDC 2004). For effective genetic improvement of grain yield, it is important to understand how the proportion of genetic component (Hamdi et al. 2003; Shukla et al. 2004) and genetic advance (Bänziger et al. 2004; Shukla et al. 2004) are affected by environments. Varalakshmi (2003) and Kumar and Yassin (2012) reported significant genotype $\times$ environment interaction for yield and its component traits in grain amaranth. This study was carried out with the objective to determine the magnitude of genetic parameters and association of traits in grain amaranth at two environments.

\section{MATERIALS AND METHODS}

Eighteen genotypes of Amaranthus cruentus and 11 genotypes of Amaranthus hypochondriacus were planted at two locations in Nigeria: Abeokuta (long. $03^{\circ} 25^{\prime} \mathrm{E}$, lat. $7^{\circ} 25^{\prime} \mathrm{N}$, alt. 159) and Ibadan (long. $3^{\circ} 89^{\prime} \mathrm{E}$, lat. $7^{\circ} 37^{\prime} \mathrm{N}$, alt. 215 ) during the late growing season in 2012 (Table 1). Rainfall distribution at the two locations is bimodal from March to September, peaking in June and September with a short dry spell in August and a long dry spell from November to March. However, Abeokuta, located in forest transitional zone, is characterised with higher precipitation, humidity, and temperature than Ibadan, derived from savanna (Table 2).

The experiment was laid out in a randomized complete block design with three replicates. Each amaranth genotype was planted in a two-row plot, 2 $\mathrm{m}$ long, at a spacing of $0.50 \mathrm{~m}$. The rows were separated by $0.50 \mathrm{~m}$. Five plants were sampled randomly from the inner portion of each plot to determine the following traits at flowering: plant height measured from soil level to the top of the plant, stem diameter measured with a venier caliper, leaf length (sixth leaf from the top of the plant) measured from tip of the leaf to the point of attachment to the petiole, leaf width (sixth leaf from the top of the plant) measured at the widest part of the leaf, petiole length measured from the base of the leaf to the point of attachment to the stem, leaf area $\left(\mathrm{cm}^{2}\right)$ estimated with the regression equation $y=0.93+0.63 x$ where $\mathrm{x}$ is the product of length and width of leaf (Adetimirin 2007), number of leaves, and days to $50 \%$ flowering (from sowing till appearance of flowers on $50 \%$ of plants). Inflorescence length (cm) measured from the base to the tip of the inflorescence; 1,000 seed weight (g) and seed yield per plant $(\mathrm{g})$ were also evaluated.

Table 1. Genotypes of amaranth and their origination evaluated during the growing season 2012 at Abeokuta and Ibadan

\begin{tabular}{llll}
\hline \multicolumn{2}{c}{ Amaranthus cruentus } & \multicolumn{2}{c}{$\begin{array}{c}\text { Amaranthus } \\
\text { hypochondriacus }\end{array}$} \\
\hline Genotype & Source & Genotype & Source \\
\hline AM25 & ARDC & NG205 & NHRI \\
AM45 & ARDC & NG412 & NHRI \\
AM48 & ARDC & Pi59 & NCGRB \\
AHNL & ARDC & Z006 & RICP \\
NG103 & NHRI & Z007 & RICP \\
NG217 & NHRI & Z009 & RICP \\
NGB105 & NHRI & Z038 & RICP \\
NHGB086 & NHRI & Z130 & RICP \\
NG10 & NHRI & Z150 & RICP \\
AMA08 & NCGRB & Z002 & RICP \\
TIBET50 & NCGRB & AM12 & ARDC \\
AM50 & NCGRB & & \\
Z004 & RICP & & \\
Z008 & RICP & & \\
Z010 & RICP & & \\
Z081 & RICP & & \\
Z151 & RICP & & \\
Z152 & RICP & & \\
\hline
\end{tabular}

ARDC - Asian Research and Development Centre, Tanzania NHRI - National Horticultural Research Institute, Nigeria NCGRB - National Centre for Genetic Resources and Biotechnology, Nigeria

RICP-Research Institute and Crop Production, the Czech Republic

Table 2. Main characteristics of the weather conditions at the experimental locations during the season 2012 and on an average over 10 years (2002-2012) (in brackets)

\begin{tabular}{lcc}
\hline \multicolumn{1}{c}{ Weather } & $\begin{array}{c}\text { Abeokuta } \\
\text { FUNAAB }\end{array}$ & $\begin{array}{c}\text { Ibadan } \\
\text { NIHORT }\end{array}$ \\
\hline $\begin{array}{l}\text { Minimum tem- } \\
\text { perature }\left({ }^{\circ} \mathrm{C}\right)\end{array}$ & $27.4(23.3)$ & $23.0(22.5)$ \\
$\begin{array}{l}\text { Maximum tem- } \\
\text { perature }\left({ }^{\circ} \mathrm{C}\right)\end{array}$ & $37.6(32.2)$ & $30.1(31.6)$ \\
$\begin{array}{l}\text { Rainfall }(\mathrm{mm}) \\
\text { Relative humid- } \\
\text { ity }(\%)\end{array}$ & $146.6(161.7)$ & $92.8(102.6)$ \\
\hline
\end{tabular}

Sources: Agro-meteorology stations of Federal University of Agriculture, Abeokuta (FUNAAB), and National Horticultural Research Institute (NIHORT), Ibadan 
Data obtained in the experiment conducted in both locations were averaged over single plant basis per replicate for analyses according to the following analysis of variance (ANOVA) mixed model:

$$
y_{i j k}=m+b(l)_{j k}+g_{i}+l_{j}+g l_{i j}+e_{i j k}
$$

where $y_{i j k}$ is an observation of the $i$ th genotype in the $j$ th location and the $k$ th replicate, $m$ the general mean, $b(l)_{j k}$ the random block within location effect, $g_{i}$ the random genotype effect, $l_{j}$ the fixed location effect, $g l_{i j}$ the random genotype $\times$ location interaction effect, and $e_{i j k}$ the random error.

The phenotypic variances of the genotypic means calculated across replicates and locations $\left(\sigma_{p}^{2}\right)$ of grain yield and its components were defined as $\sigma_{\mathrm{p}}^{2}=\sigma_{g}^{2}+\frac{\sigma_{g l}^{2}}{l}+\frac{\sigma_{e}^{2}}{r l}$ where $\sigma_{g}^{2}$ is the genotypic variance, $\sigma_{g l}^{2}$ the genotype $\times$ location interaction variance, $\sigma_{e}^{2}$ the error variance, $r$ the number of replicates, and $l$ the number of locations.

Variance components of the effects were evaluated using the Proc mixed cov test method type III procedure of SAS version 9.1.1 (SAS 2000).

For each location in the data analysis, according to the random model as $y_{i j}=m+b_{j}+g_{i}+e_{i j}$, phenotypic variances of the genotypic means calculated across replicates $\left(\sigma_{p}^{2}\right)$ of grain yield and its components were defined as $\sigma_{p}^{2}=\sigma_{g}^{2}+\frac{\sigma_{e}^{2}}{r}$ where $\sigma_{g}^{2}$ is the genotypic variance, $\sigma_{e}^{2}$ the error variance, and $r$ the number of replicates (Miller 1974).

Based on the variance components, the following parameters were estimated: phenotypic coefficient of variability $(P C V)=\frac{\sqrt{\sigma_{p}^{2}}}{\bar{x}} \times 100$, genotypic coefficient of variability $(G C V)=\frac{\sqrt{\sigma_{g}^{2}}}{\bar{x}} \times 100$, and heritability $\left(h^{2}=\frac{\sigma_{g}^{2}}{\sigma_{p}^{2}}\right)$ where $\bar{x}$ is the grand mean of the trait. Phenotypic, genotypic, and environmental correlation coefficients between grain yield and other characters were estimated: $\frac{\operatorname{Covxy}}{\sqrt{\sigma_{x}^{2} \times \sigma_{y}^{2}}}$ where $\sigma_{x}^{2}$ and $\sigma_{y}^{2}$ represent genotypic and environmental variances of character $x$ and grain yield $(y)$, respectively, and $\operatorname{Cov}_{x y}$ is covariance between character $x$ and $y$ using Microsoft Excel.

Assuming selection differential $(k)$ of $5 \%$, genetic gain was estimated for direct selection of grain yield as $\sigma_{p} \times h^{2} \times k$ and indirect selection of grain yield through other characters as , $k \times h_{x}^{2} \times h_{y}^{2} \times \sigma_{p(y)}$ where $h_{x}^{2}$ and $h_{y}^{2}$ are heritability estimates of $x$ and $y$, respectively, and $\sigma_{p(y)}$ is phenotypic variance of $y$ (Falconer 1989). Genotypic correlation coefficients were partitioned to assess direct and indirect effect of the yield-related traits on grain yield using the path coefficient analysis (Dewey \& Lu 1959; Singh \& Chaudhary 1979).

\section{RESULTS}

There were significant genotypic differences for number of leaves, leaf and petiole length, leaf area and for 1,000 seed weight and grain yield in A. cruentus. and plant height, leaf width, and days to $50 \%$ flowering. In A. hypochondriacus significant genotypic differences were for plant height, number, length, width and area of leaves, for length of petiole and no. of days for flowering (Table 3). Although the location alone had no significant effect, genotype $\times$ location significantly influenced all the analyzed traits in A. cruentus and most in A. hypochondriacus traits. Phenotypic variance of the traits was partitioned into its component variances (Table 4); genotypic variance contributed more to phenotypic variance of traits in A. hypochondriacus. Low genotypic variance for plant height, stem girth, leaf width, days to $50 \%$ flowering, and inflorescence length in A. cruentus was associated with high genotype $\times$ location variance.

Genetic parameters for the traits were explained on location basis because of the influence of genotype $\times$ location. In general, differences between the parameters of the locations were higher in A. cruentus than in A. hypochondriacus (Table 5), with higher values at Abeokuta compared to Ibadan for most traits. However, genotypic coefficient of variability, heritability, and genetic advance for inflorescence length and grain yield were higher at Ibadan than those Abeokuta in amaranth species. There is higher genetic advance for days to $50 \%$ flowering in A. cruentus at Abeokuta.

Considering association between traits, genotypic correlation coefficients between grain yield and other traits at the locations were significant (Table 6). Most traits had positive association with grain yield, except inflorescence length at Ibadan, but with difference in magnitude between locations. Lower and nonsignificant environmental correlation coefficients indicated phenotypic correlation coefficients as a reflection of genotypic correlation coefficients. 


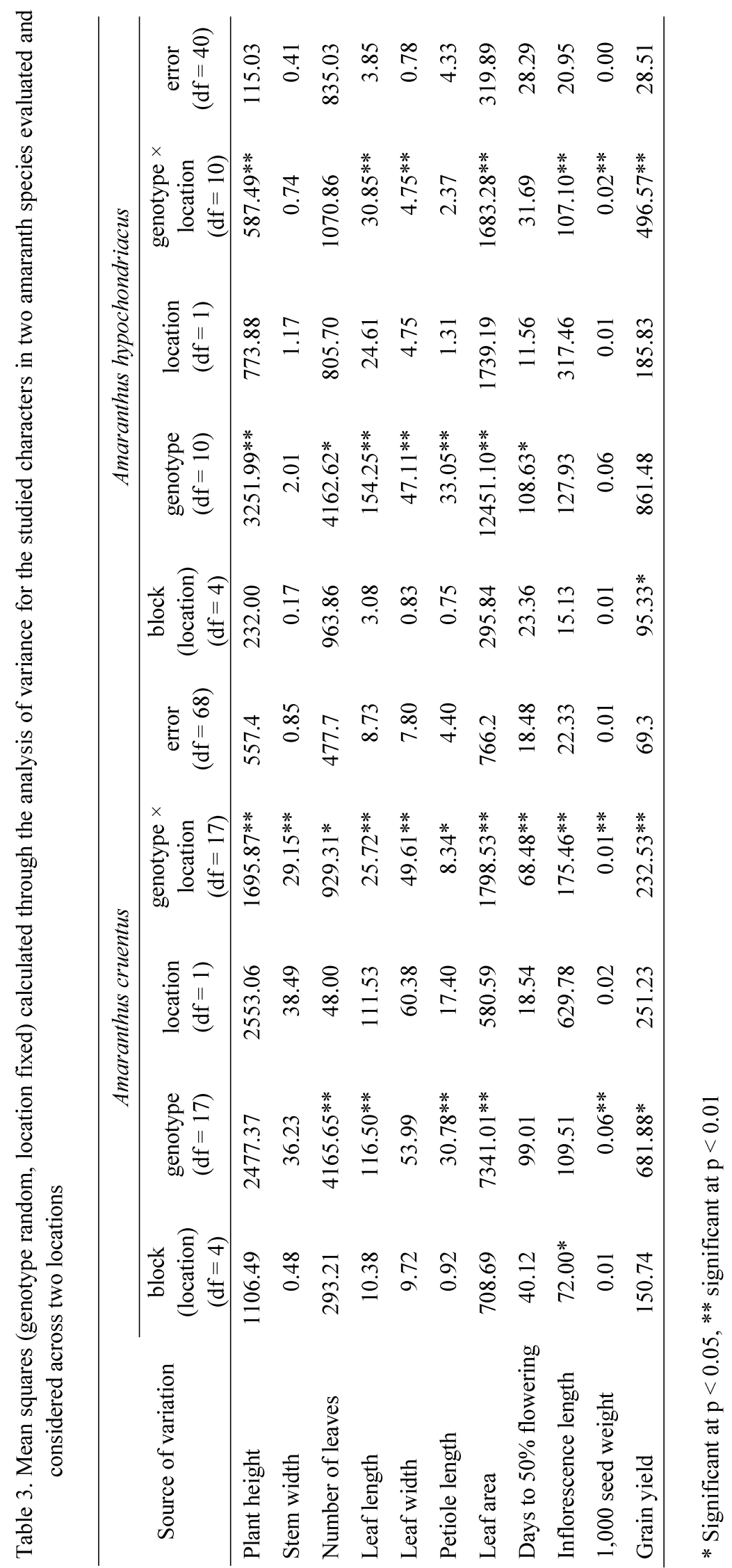


Table 4. Proportion of variance components in the phenotypic variance of the character means in two amaranth species evaluated and considered across two locations (in percentage)

\begin{tabular}{lrrrrrr}
\hline \multirow{2}{*}{\multicolumn{1}{c}{ Character }} & \multicolumn{3}{c}{ Amaranthus cruentus } & \multicolumn{3}{c}{ Amaranthus hypochondriacus } \\
\cline { 2 - 6 } & \multicolumn{1}{c}{$\delta_{g}^{2}$} & $\delta_{g l}^{2}$ & \multicolumn{1}{c}{$\delta_{e}^{2}$} & $\delta_{g}^{2}$ & $\delta_{g l}^{2}$ & \multicolumn{1}{c}{$\delta_{e}^{2}$} \\
\hline Plant height $(\mathrm{cm})$ & 31.55 & 45.96 & 22.50 & 81.93 & 14.53 & 3.54 \\
Stem girth (cm) & 19.56 & 78.11 & 2.33 & 63.51 & 16.24 & 20.26 \\
Number of leaves & 77.69 & 10.84 & 11.47 & 74.27 & 5.67 & 20.06 \\
Leaf length (cm) & 77.92 & 14.58 & 7.50 & 80.00 & 17.51 & 2.50 \\
Leaf width (cm) & 8.12 & 77.44 & 14.45 & 89.93 & 8.41 & 1.66 \\
Petiole length (cm) & 72.91 & 12.80 & 14.30 & 86.90 & 5.94 & 7.16 \\
Leaf area $\left(\mathrm{cm}^{2}\right)$ & 75.50 & 14.06 & 10.44 & 86.48 & 10.95 & 2.57 \\
Days to 50\% flowering & 30.83 & 50.50 & 18.67 & 70.82 & 3.13 & 26.04 \\
Inflorescence length (cm) & 37.59 & 49.69 & 12.72 & 16.28 & 67.34 & 16.38 \\
1000 seed weight $(\mathrm{g})$ & 78.13 & 14.06 & 7.81 & 62.50 & 30.36 & 7.14 \\
Grain yield (g) & 65.90 & 23.94 & 10.16 & 42.36 & 54.33 & 3.31 \\
\hline
\end{tabular}

$\delta_{g}^{2}$ is the genotypic variance, $\delta_{g l}^{2}$ the genotype $\times$ location interaction variance and $\delta_{e}^{2}$ the error variance

Table 5. Coefficients of genotypic variability, heritability, and genetic advance of characters in two amaranth species considered separately in each location

\begin{tabular}{lrrrrrr}
\hline \multirow{2}{*}{\multicolumn{1}{c}{ Character }} & \multicolumn{2}{c}{ GCV } & \multicolumn{2}{c}{$h^{2}$} & \multicolumn{2}{c}{ Genetic advance } \\
\cline { 2 - 7 } & Abeokuta & Ibadan & Abeokuta & Ibadan & Abeokuta & Ibadan \\
\hline Amaranthus cruentus & & & & & & \\
Plant height (cm) & 38.54 & 21.34 & 0.83 & 0.56 & 0.73 & 0.33 \\
Stem diameter (cm) & 149.23 & 26.26 & 0.99 & 0.40 & 3.06 & 0.34 \\
Number of leaves & 46.29 & 41.80 & 0.80 & 0.82 & 0.85 & 0.78 \\
Leaf length (cm) & 36.40 & 30.43 & 0.92 & 0.84 & 0.72 & 0.57 \\
Leaf width (cm) & 59.03 & 30.11 & 0.86 & 0.82 & 1.12 & 0.56 \\
Petiole length (cm) & 38.66 & 32.82 & 0.86 & 0.70 & 0.74 & 0.56 \\
Leaf area (cm2) & 53.70 & 47.29 & 0.88 & 0.79 & 1.04 & 0.86 \\
Days to 50\% flowering & 9.30 & 2.33 & 0.93 & 0.22 & 0.18 & 0.02 \\
Inflorescence length (cm) & 7.61 & 52.17 & 0.42 & 0.87 & 0.10 & 1.00 \\
1,000 seed weight (g) & 27.70 & 28.99 & 0.80 & 0.94 & 0.51 & 0.58 \\
Seed yield & 27.94 & 42.93 & 0.81 & 0.87 & 0.52 & 0.83 \\
A. hypochondriacus & & & & & & \\
Plant height (cm) & 49.21 & 25.78 & 0.96 & 0.89 & 0.99 & 0.50 \\
Stem girth (cm) & 39.99 & 30.54 & 0.81 & 0.60 & 0.74 & 0.49 \\
Number of leaves & 48.60 & 49.01 & 0.68 & 0.68 & 0.83 & 0.83 \\
Leaf length(cm) & 44.08 & 41.96 & 0.96 & 0.95 & 0.89 & 0.84 \\
Leaf width (cm) & 47.41 & 46.92 & 0.98 & 0.96 & 0.97 & 0.95 \\
Petiole length (cm) & 50.12 & 37.98 & 0.87 & 0.60 & 0.97 & 0.60 \\
Leaf area (cm2) & 84.93 & 75.57 & 0.97 & 0.94 & 1.72 & 1.51 \\
Days to 50\% flowering & 5.33 & 5.86 & 0.57 & 0.62 & 0.08 & 0.09 \\
Inflorescence length (cm) & 9.59 & 49.11 & 0.58 & 0.91 & 0.15 & 0.96 \\
1,000 seed weight (g) & 32.73 & 26.77 & 0.90 & 0.89 & 0.64 & 0.52 \\
Grain yield (g) & 25.09 & 60.86 & 0.82 & 0.98 & 0.47 & 1.24 \\
\hline
\end{tabular}

GCV is the genotypic coefficient of variation and $h^{2}$ is the heritability. 
Table 6. Phenotypic, genotypic, and environmental correlation coefficients between grain yield and yield-related characters and correlated response of grain yield considered separately in each location

\begin{tabular}{lllrllllr}
\hline \multirow{2}{*}{\multicolumn{1}{c}{ Character }} & \multicolumn{4}{c}{ Abeokuta } & \multicolumn{4}{c}{ Ibadan } \\
\cline { 2 - 9 } & \multicolumn{1}{c}{$r_{p}$} & \multicolumn{1}{c}{$r_{g}$} & \multicolumn{1}{c}{$r_{e}$} & \multicolumn{1}{c}{$r_{p}$} & \multicolumn{1}{c}{$r_{g}$} & \multicolumn{1}{c}{$r_{e}$} & $C R$ \\
\hline Plant height & $0.55^{* *}$ & $0.65^{* *}$ & -0.02 & 9.29 & $0.27^{* *}$ & $0.36^{* *}$ & -0.16 & 8.21 \\
Stem diameter & $0.25^{*}$ & $0.29^{* *}$ & -0.07 & 4.55 & $0.23^{*}$ & $0.40^{* *}$ & -0.20 & 6.07 \\
Number of leaves & 0.06 & 0.07 & 0.02 & 0.84 & 0.17 & $0.21^{*}$ & -0.08 & 5.24 \\
Leaf length & $0.51^{* *}$ & $0.59^{* *}$ & -0.01 & 8.88 & $0.25^{*}$ & $0.35^{* *}$ & 0.06 & 5.49 \\
Leaf width & $0.38^{* *}$ & $0.43^{* *}$ & 0.12 & 6.12 & $0.34^{* *}$ & $0.37^{* *}$ & -0.03 & 10.55 \\
Petiole length & $0.59^{* *}$ & $0.71^{* *}$ & -0.03 & 9.99 & $0.32^{* *}$ & $0.40^{* *}$ & -0.04 & 9.28 \\
Leaf area & $0.57^{* *}$ & $0.65^{* *}$ & 0.05 & 9.57 & $0.33^{* *}$ & $0.37^{* *}$ & 0.02 & 9.98 \\
Days to 50\% flowering & $0.27^{* *}$ & $0.32^{* *}$ & 0.06 & 4.16 & 0.18 & $0.21^{*}$ & 0.08 & 4.39 \\
Inflorescence length & $0.28^{* *}$ & $1.36^{* *}$ & 0.10 & 0.82 & $-0.29^{* *}$ & $-0.32^{* *}$ & -0.06 & -8.77 \\
1,000 seed weight & $0.46^{* *}$ & $0.60^{* *}$ & -0.12 & 7.63 & $0.37^{* *}$ & $0.38^{* *}$ & 0.26 & 10.94 \\
\hline
\end{tabular}

$r_{p}$ is the phenotypic correlation coefficient, $r_{g}$ the genotypic correlation coefficient), $r_{e}$ the environmental correlation coefficient, and CR the correlated response of grain yield.

* Significant at $\mathrm{p}<0.05$, ** significant at $\mathrm{p}<0.01$, degree of freedom at $\mathrm{n}=87$.

Genotypic performance for grain yield was explained more by other traits at Abeokuta, 0.29 (stem width) to 1.36 (inflorescence length), than those at Ibadan, 0.21 (days to $50 \%$ flowering and number of leaves) to 0.40 (stem width and petiole length). Plant height, leaf length, and petiole length had high correlated response with grain yield at Abeokuta and with leaf width, petiole length, leaf area, and 1,000 seed weight at Ibadan.

Direct and indirect contribution of traits to genotypic correlation coefficients revealed high magnitude and positive direct effect of petiole length and leaf length on grain yield at Abeokuta. Leaf area had high and negative direct effect on grain yield. Other traits had negative indirect effect on grain yield through leaf area and high positive indirect influence on grain yield through leaf length and petiole length. However, all traits except plant height and leaf length had positive direct contribution to yield with high indirect influence through petiole length and leaf area at Ibadan. In both locations, tall plants are associated with low grain yield.

\section{DISCUSSION}

Diversity of genetic resources is an important component in crop breeding program. Its amount determines the extent to which selection can be done and the magnitude of the genetic parameters controlling the traits estimates the response to and gain expected from selection. However, the amount of genetic components and direction of association between traits may vary with the environment (Obilana \& Fakorede 1986; Bänziger et al. 2004). Knowledge of the values of genetic parameters in different environments can ensure effective selection and thus progress in breeding (Hamdi et al. 2003; Shukla et al. 2004).

The present study revealed the significance of genotype $\times$ location on the traits which in turn influenced changes in magnitude of the genetic components between locations. Differential response of genotypes to environment could be responsible for variation of traits between the locations. Abeokuta, with usually higher than Ibadan precipitation, humidity, and temperature, influenced more GCV, heritability, and genetic advance of traits in grain amaranth. This suggested response of amaranth for high genetic diversity in a humid and warm environment. However, higher gain for genetic improvement of inflorescence length and grain yield is expected at Ibadan. Also, considering association between traits in amaranth, grain yield can be improved simultaneously with other traits but the selection criteria varied with location. 


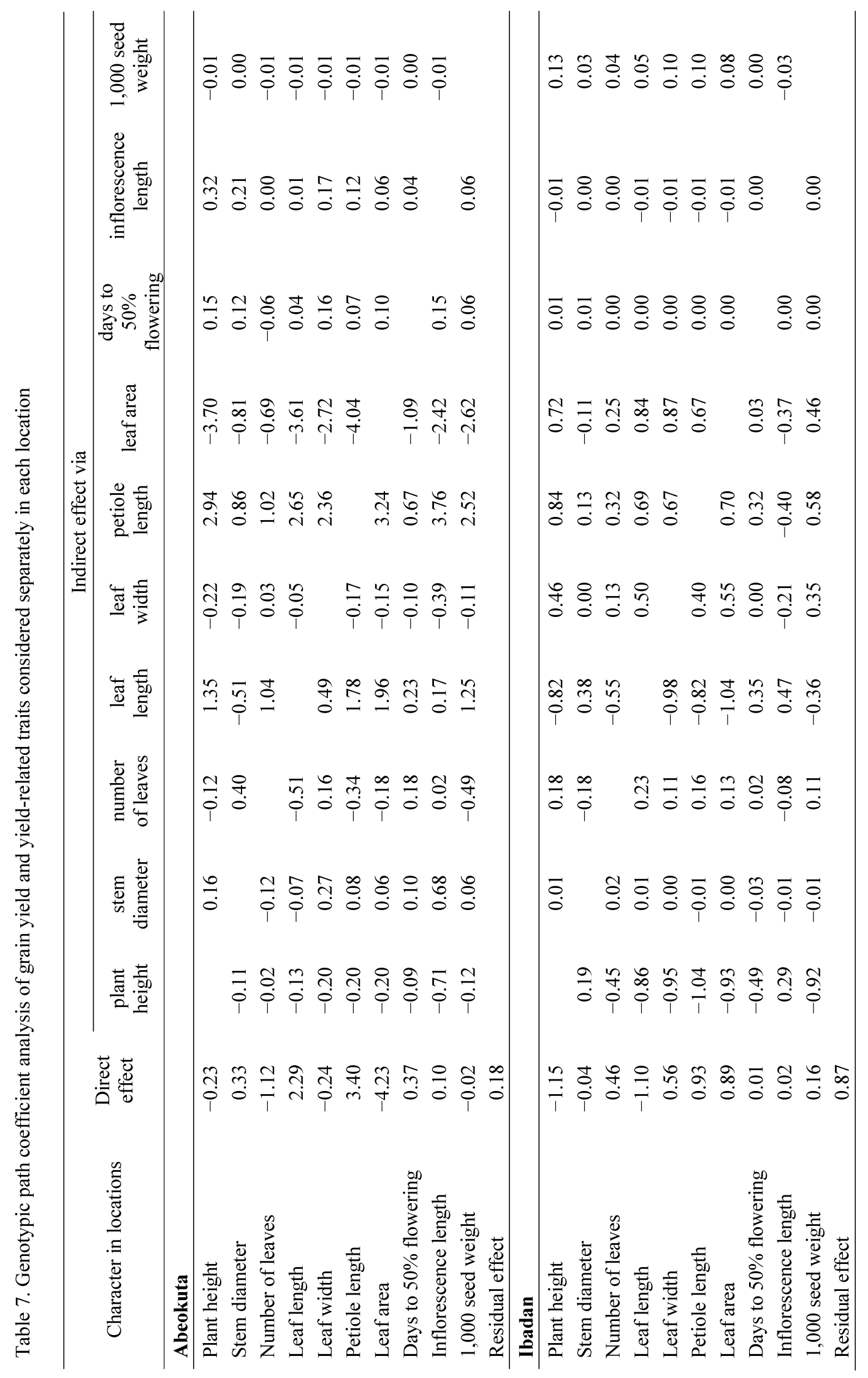


In conclusion, these findings suggest planning of breeding program that considers the effect of environment on genetic gain. This will allow the choice of the most suitable selection strategy to reduce the time for cultivar development.

\section{REFERENCES}

Adetimirin V.O. 2007. Modelling grain amaranth leaf area from linear measurements. Nigerian Journal of Science 41: 76-89.

Alvarez-Jubete L., Wijngaard H., Arendt E.K., Gallagher E. 2010. Polyphenol composition and in vitro antioxidant activity of amaranth, quinoa, buckwheat and wheat as affected by sprouting and baking. Food Chemistry 119: 770-778. DOI: 10.1016/j.foodchem.2009.07.032.

Andini R., Yoshida S., Ohsawa R. 2013. Variation in protein content and amino acids in the leaves of grain, vegetable and weedy types of amaranths. Agronomy 3: 391-403. DOI: 10.3390/agronomy3020391.

AVRDC 2004. Seed production and processing in indigenous vegetables. In: Kalb T. (Ed.), AVRDC Report 2003. Shanhua, Taiwan, AVRDC - The World Vegetable Center, pp. 29-31.

Bänziger M., Setimela P.S., Hodson D., Vivek B. 2004. Breeding for improved drought tolerance in maize adapted to southern Africa. In: Fischer T. et al. (Eds.), New directions for a diverse planet. Proceedings of the $4^{\text {th }}$ International Crop Science Congress, 26 Sept.-1 Oct. 2004, Brisbane, Australia.

Bhuvaneswari G., Sharada G.S., Patil V.C. 2001. Nutrient composition of grain amaranth varieties. Karnataka Journal of Agricultural Sciences 14 (3): 869-870.

Dewey D.R., Lu K.H. 1959. A correlation and path-coefficient analysis of components of crested wheat grass seed production. Agronomy Journal 51: 515-518. DOI: 10.2134/agronj1959.00021962005100090002x.

Drzewiecki J., Delgado-Licon E., Haruenkit R., Pawelzik E., Martin-Belloso O., Park Y.S. et al. 2003. Identification and differences of total proteins and their soluble fractions in some pseudocereals based on electrophoretic patterns. Journal of Agricultural and Food Chemistry 51(26): 7798-7804. DOI: 10.1021/jf030322x.

Dubois T., Stoilova T. 2015. Some traditional African vegetables and the challenges involving for popularizing them. Workshop to develop a Curriculum on Neglected and Underutilized Species (NUS),
22-24 September 2015, Biodiversity, World Agroforestry Centre, ANAFE.

Falconer D.S. 1989. Introduction to qualitative genetics, $2^{\text {nd }}$ ed. Longman, London, $340 \mathrm{p}$.

Girija K., Lakshman K., Udaya C., Sabhya S.G., Divya T. 2011. Anti-diabetic and anti-cholesterolemic activity of methanol extracts of three species of Amaranthus. Asian Pacific Journal of Tropical Biomedicine 1(2): 133-138. DOI: $10.1016 / \mathrm{S} 2221-$ 1691(11)60011-7.

Gonor K.V., Pogozheva A.V., Derbeneva S.A., Mal'tsev G., Trushina E.N., Mustafina O.K. 2006. The influence of a diet with including amaranth oil on antioxidant and immune status in patients with ischemic heart disease and hyperlipoproteidemia. Voprosy Pitaniia 75(6): 30-33. [in Russian]

Grubben G.J.H., Denton O.A. 2004. Plant Resources of Tropical Africa 2: Vegetables. PROTA, Wageningen, Netherlands, $668 \mathrm{p}$.

Hamdi A., El-Ghareib A.A., Shafey S.A., Ibrahim M.A.M. 2003. Genetic variability, heritability and expected genetic advance for earliness and seed yield from selection in lentil. Egyptian Journal of Agricultural Research 81(1): 125-137.

Kumar S.R., Yassin G.M. 2012. "G x E interaction for grain yield and its contributing traits in grain amaranthus. International Journal of Agricultural Sciences 2(10): 266-272.

Maundu P.M., Grubben G.J.H. 2004. Amaranthus graecizans L. In: Grubben G.J.H. and Denton O.A. (Eds.) PROTA 2: Vegetables/Légumes [CD-Rom]. Wageningen, The Netherlands. pp.: 76-78.

Martirosyan D.M., Miroshnichenko L.A., Kulakova S.N., Pogojeva A.V., Zoloedov V.I. 2007. Amaranth oil application for coronary heart disease and hypertension. Lipids in Health and Disease 6: 1. DOI: $10.1186 / 1476-511 X-6-1$.

Miller R. G. 1974. The jackknife: A review. Biometrika 61: 1-15. DOI: 10.1093/biomet/61.1.1.

Obilana A.T., Fakorede M.A.B. 1986. Heritability: A Treatise. Samaru Journal of Agricultural Research 1: 72-82.

Alemayehu F.R., Bendevis M., Jacobsen S.-E. 2014. The potential for utilizing the seed crop amaranth (Amaranthus spp.) in East Africa as an alternative crop to support food security and climate change mitigation. Journal of Agronomy and Crop Science 201: 321-329. DOI: 10.1111/jac.12108.

Sangameswaran B., Jayakar B. 2008. Anti-diabetic, antihyperlipidemic and spermatogenic effects of Amaranthus spinosus Linn. on streptozotocin-induced 
diabetic rats. Journal of Natural Medicines 62: 7982. DOI: $10.1007 / \mathrm{s} 11418-007-0189-9$.

SAS Institute 2000. SAS Linear model: A guide to ANOVA and GLM procedures. SAS Institute, Cary, NC.

Shukla S., Bhargava A., Chatterjee A., Singh S.P. 2004. Estimates of genetic parameters to determine variability for foliage yield and its different quantitative and qualitative traits in vegetable amaranth (A. tricolor). Journal of Genetics and Breeding 58: 169-176.

Singh R.K., Chaudhary B.D. 1979. Biometrical methods in quantitative genetic analysis, $2^{\text {nd }}$ ed. Kalyani publishers, New Delhi.
Tironi V.A, Añón M.C. 2010. Amaranth proteins as a source of antioxidant peptides: Effect of proteolysis. Food Research International 43: 315-322. DOI: 10.1016/j.foodres.2009.10.001

Yanez G.A., Messinger J.K., Walker C.E., Rupnow J.H. 1986. Amaranthus hypochondriacus: starch isolation and partial characterization. Cereal Chemistry 63: 273-276.

Varalakshmi B. 2003. Phenotypic stability for economic traits in vegetable amaranth (Amaranthus tricolor). Indian Journal of Agricultural Sciences 73(2): 114115. 